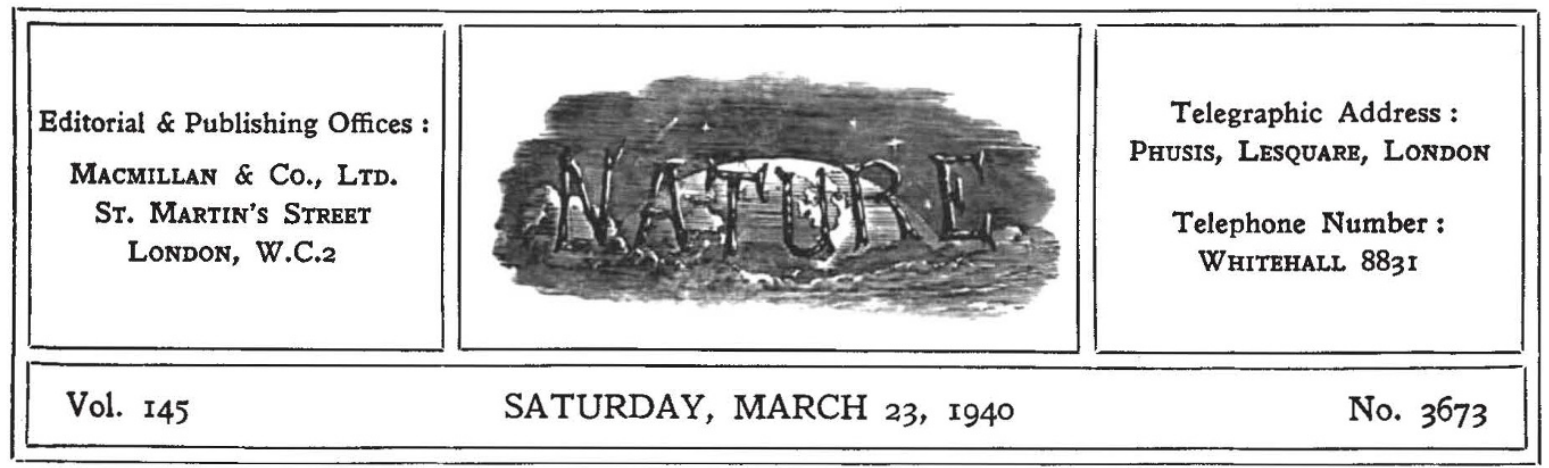

\title{
METHODS AND AIMS IN AMERICAN ARCHÆOLOGY
}

$\mathrm{A}^{\mathrm{H}}$ LTHOUGH archæologists in the United States welcomed the financial assistance afforded field research and excavation by the measures taken by the Federal and State Government authorities for the relief of unemployment, their satisfaction was tempered by some misgiving. It is true that it now became possible to open up sites long marked as desirable for investigation, but of which the examination had to be postponed while the funds available were devoted to purposes of more insistent urgency in their bearing upon major archæological problems. At the same time, it was recalled to how great an extent the antiquities of the remarkable and unique indigenous civilization of the Americas had suffered from amateur and untrained trophy hunting. Further, public works were being inaugurated or accelerated which would add to the destruction on a vastly extended scale. The construction of a great dam in the Tennessee Valley during the War of 1914-18, for example, had inundated twenty-three square miles of country, and to this the projected scheme of the Tennessee Valley Authority would add a further 100 square miles, both tracts taken from a territory thickly studded with relics of Indian occupation, of which so considerable a proportion would now be lost for ever to archæological study. It was evident that there was an urgent call both for trained and skilled supervisors of excavations and public works, and for a scheme of conservation to preserve as much as was possible of the evidence of antiquity for study by posterity.

As an outcome of this apprehension, the matter was taken in hand by the National Research Council. In April 1939, the Division of Anthropology and Psychology of that body appointed a committee to study the needs of American archæology. This committee was composed of some of the most active among practising archæologists of the United States; among them were Dr. A. D. Strong, who acts as chairman, Dr. Clark Wissler, Dr. A. V. Kidder, Prof. Fay Cooper Cole, and Dr. W. S. Webb. The Committee has already published a report of a preliminary nature, of which an analysis by Dr. Carl E. Gutha, chairman of the Division of Social Sciences of the National Research Council, appeared in Science of December 8, 1939.

It has been pointed out recently that in the study of the indigenous civilization of the Americas, but more especially of the northern half of the continent, the distinction in method and outlook between archæological studies and ethnography and ethnology is by no means so strongly marked as it is, as a rule, in the study of Old World civilizations. On one hand, archæological methods and arguments more and more have to be applied to the reconstruction of an Indian cultural complex, while on the other hand interpretation of archæological data may be illumined by reference to the evidence of ethnography recording traditional Indian custom and belief, a source of which perhaps the fullest use has not always been made. Why Americanist studies should be peculiarly favoured in this way must be obvious. For one thing, American civilization, when once the tide of early immigrant peoples ceased to flow, remained virtually free from serious outside cultural and racial influence for some centuries-or at least so those of us would believe who are not diffusionists-until the impact of European civilization, at first of the Norsemen, though this is virtually negligible, and 
afterwards of other European peoples in the late fifteenth and sixteenth centuries. Further, and partly as a consequence of this prolonged isolation, American civilization shows a remarkable continuity of development, as well as a stability of condition, which has affected not merely the indigenous population but also the development of white civilization, a fact which writers on American civilization in its broader aspect have perhaps sometimes failed adequately to stress.

If we ignore the industrial zone and areas of mineral exploitation, American civilization is still based on agriculture and animal exploitation, though it is true that the place of the hunter and the bison is taken by the cowboy and vast flocks and herds of domesticated animals. Even though corn now grows in the plains where the bison once was hunted, this implies no break in the cycle of cultural development, for even as the agriculturist in the Old World has displaced the hunter, so in America the farmer has edged the herdsman off the lands which generations of wild cattle had fertilized for his crops of corn. The readiness of the early settlers and pioneers to adopt elements from indigenous culture, many of which survive to this day, bears testimony to the influence of the continental environment in moulding the technique of living from day to day.

It is evident that some such conception of the function of archæology in Americanist studies, as illustrative of a continuous development, was present in the collective mind of the Committee in deciding on the scope and in framing the terms of the preliminary report. The sphere of interest of that report, it was felt, was best limited to "an analysis of the principles which govern the methods and procedures of American archæological research" and could most usefully indicate its basic needs.

As herein formulated, the aim of American archæology is said to be "to make the past live again; to preserve for posterity the story of the rise and spread of early cultures on the Americun continent and their influence on white settlement". From such studies, it is pointed out, much may be learned, not only in the field of human history, but also of such significant subjects as long-continued land utilization, cycles of climatic change and the history of important agricultural crops. It is interesting to note the implicit recognition of the fact that, given continuity of environmental and climatic conditions, an academic problem in archæology may have a practical bearing on the affairs of even such a progressive modern community as is found in contemporary American civilization.

The Committee recognizes fully that much excellent work has already been done and experience gained, as well as much valuable information gathered, through the assistance granted by Federal and State schemes for the relief of unemployment or in rescuing prehistoric records in districts about to be flooded. Yet in view of the fact that these relief projects are to be continued, and others are contemplated, it has been thought urgent that a statement should be issued at the earliest possible moment, giving the minimum requirements with which future work, whether public or private, should comply, in order to attain a standard of scientific accuracy satisfactory for the needs of archæological studies. In view of the stress laid upon general principles of archæological research and conservation, this document is of more than merely local interest.

In framing its statement of these requirements, the aim of the Committee has been to eliminate anything and everything in the nature of haphazard excavation. With this in view, it has covered every stage of the research in broad outline from its initiation, concerning which it is laid down that "a definite need should be shown for the solution of a well-defined archæological problem or for the conservation of prehistoric material placed in jeopardy by public works or other agencies, whether natural or human", down to final publication of a report which, it is insisted, should be as speedy as possible after the completion of the investigation. In regard to this latter point, however, it is emphasized that archæological investigation and 'hustle' have no affinities.

The Committee has laid down in some detail the organization for which a scientific institution or learned society must be prepared to provide when undertaking the responsibility for a research project under any one of the schemes fathered by Government authority. That responsibility cannot be regarded as ceasing with the provision of skilled archæological supervision. To this must be added the field staff, with academic training and field experience, competent to keep proper records in addition to carrying out the practical work of surveying, excavating or conducting the technical work of the laboratory, with, be it said, the complete equipment of technical apparatus, cameras, surveying instruments and the like, which each department of this work demands. A somewhat higher degree of specialization in function is 
demanded than is commonly practised; but the useful principle is laid down that whereas the methods of the field and the laboratory differ, there should be one director who is supreme over both departments.

It is unnecessary to follow the Committee through all its detail of instructions. It will suffice to say that these are such as to satisfy an exacting standard. Two matters, however, may be specially mentioned. In view of the amount of detailed record required, the need of adequate clerical assistance to relieve the director and archæological staff is emphasized; and secondly, it is pointed out that in view of the need for national conservation-a basic need-not only should each site opened be excavated with the greatest care, the material carefully studied and the results fully published, but also certain sites in every area should be carefully preserved for research in the future as new techniques are developed; this last is a requirement of much wisdom, which Sir Flinders Petrie impressed upon excavators of archæological sites in the Old World many years ago.

The Committee ends its admonitions to the prosecution of such "forward looking activities" by pointing out their application, not only to academic bodies, but also to the National Park service, State historical societies, and municipalities, to which such studies should appeal as advancing the growth of national consciousness. At the same time, the soundest piece of advice given is that reserved for the last, namely, that if the foregoing minimum requirements cannot be fully met by any Federal, State, or local institution, it should not undertake archæological research at all.

Notwithstanding the different circumstances of the Old World and the New, the line of approach to their problem adopted by the archæologists of the United States is not without its lesson for their fellow-workers elsewhere. In method and technique, except as regards completeness of organization, it may be that there is little to be learned. In regard to the future of archæological studies, however, while no one can foretell what post-War conditions may bring forth, it may be assumed that greater economy of effort and a greater measure of co-operation than has prevailed hitherto will be demanded. The direction of research to crucial problems, which would seem a necessary corollary, demands a survey, no less comprehensive and no less authoritative than that now in progress in America, for which the temporary check in field work affords an opportumity.

\section{THE RELATION OF SCIENCE TO DEMOCRACY}

\section{(I) Democracy}

Today and Tomorrow. By Eduard Benes. Pp. $x+244$. (London: Macmillan and Co., Ltd., 1939.) $8 s .6 d$. net.

\section{(2) For Democracy}

Edited by the "People and Freedom" Group. Pp. $x+$ 237. (London: Burns, Oates and Washbourne, Ltd., 1939.) $8 s .6 d$. net.

\section{(3) Spiritual Values and World Affairs}

By Sir Alfred Zimmern. Pp. vi + 178. (Oxford: Clarendon Press; London: Oxford University Press, 1939.) 7s. 6d. net.

THE growing concern of scientific workers with the social consequences of the application of scientific knowledge, and the deepening interest in the scientific investigation of social problems, of which the formation of the new Division for the Social and International Relations of Science of the British Association is only one illustration, have been prompted at least in part by the realization that the nature of the society in which they work has a powerful influence on the direction, and even the nature, of scientific work. This, and the increasing extent to which scientific and technical factors are involved in the solution of major administrative problems in national and international affairs, have induced many scientific workers to overcome their habitual dislike or distrust of political matters sufficiently to take a much closer interest in forces which may have such a powerful influence on their own work.

While, however, the events of recent years have made the maintenance of professional integrity and independence of increasing importance if the scientific worker is to continue his disinterested and dispassionate search for truth, and at the same time have indicated the dangers attendant on his allowing himself to be drawn into party politics or committing himself to the support of policies or statements in fields of which he has no 